\title{
SARS-COV-2 INFECTION AND THYROID DISEASES
}

\author{
SARS-COV-2 ENFEKSIYONU VE TIROID HASTALIKLARI
}

\section{Özlem ÇELIK'}

\begin{abstract}
${ }^{1}$ Acibadem University, Acibadem Medical School, Department of Internal Medicine, Division of Endocrinology and Metabolism, Istanbul, Turkey
\end{abstract}

ORCID IDs of the authors: Ö.Ç. 0000-0002-7254-0757

Cite this article as: Celik O. Sars-CoV-2 infection and thyroid diseases. J Ist Faculty Med 2021;84(4):590-4. doi: 10.26650/IUITFD.2021.939684

\section{ABSTRACT}

The severe acute respiratory syndrome-coronavirus-2 (SARSCoV-2) virus, was identified as the cause of a pandemic of respiratory illness in Wuhan, China one year ago. The Coronavirus disease 2019 (COVID-19), may cause mild disease with nonspecific signs and symptoms such as fever, cough, myalgia, and fatigue, or severe pneumonia with respiratory failure and sepsis. However, endocrinological manifestations are yet to be established, in patients with COVID-19. The effect of COVID-19 on thyroid function is unknown at this time. Evidence support that patients with COVID-19 who are followed up in intensive care units may develop thyroid dysfunction as a non-thyroidal illness syndrome. Until now, twenty-two cases with subacute thyroiditis and five cases with Graves' Diseases potentially associated with SARSCoV-2 infection have been reported in literature. Physicians should be aware of possible relationships between thyroid dysfunction and COVID-19. This study aimed to review thyroid dysfunction in patients with COVID-19, and to overview thyroid diseases that are probably related to COVID-19.

Keywords: COVID-19, SARS-CoV-2, thyroid, non-thyroidal illness syndrome, subacute thyroiditis, Graves' disease

\begin{abstract}
ÖZET
Şiddetli akut solunum sendromu-koronavirüs-2 (SARS-CoV-2) virüsü, bir yıl önce Çin'in Wuhan kentinde bir solunum yolu hastalığı salgınının nedeni olarak tanımlandı. Coronavirus hastalığı 2019 (COVID-19), ateş, öksürük, miyalji ve yorgunluk gibi spesifik olmayan bulgu ve semptomlarla hafif hastalığa veya solunum yetmezliği ve sepsisle birlikte şiddetli pnömoniye neden olabilir. Bununla birlikte, COVID-19 hastalarında endokrinolojik belirtiler henüz tanımlanmamıştır. Şu anda, COVID-19'un tiroid fonksiyonu üzerinde bir etkisinin olup olmadığı belirsizdir. Kanıtlar yoğun bakım ünitelerinde takip edilen COVID-19 hastalarının hasta ötiroid sendrom olarak tiroid disfonksiyonu geliştirebileceklerini desteklemektedir. Şimdiye kadar, literatürde potansiyel olarak SARS-CoV-2 enfeksiyonu ile ilişkili yirmi iki subakut tiroidit vakası ve beş Graves' hastalığı vakası bildirilmiştir. Hekimler, tiroid disfonksiyonu ile COVID-19 arasındaki olası ilişkilerin farkında olmalıdır. Bu derlemede, COVID-19 hastalarında tiroid disfonksiyonu ve muhtemelen COVID-19 ile ilişkili tiroid hastalıklarının gözden geçirilmesi amaçlanmıştır.
\end{abstract}

Anahtar Kelimeler: COVID-19, SARS-CoV-2, tiroid, non-tiroidal hastalık sendromu, subakut tiroidit, Graves' hastalığı

\section{INTRODUCTION}

Coronavirus disease 2019 (COVID-19), which is caused by the severe acute respiratory syndrome-coronavirus-2 (SARS-CoV-2) virus, has already become a pandemic just a few months after it was first reported in China (1). The virus penetrates the body via upper respiratory mucous membranes and then spreads to the lungs. The majority of COVID-19 patients suffer from a mild to moderate illness (fever, cough, myalgia, fatigue) or viral pneumonia after an incubation period of 2-14 days (median five days). However, some patients experience serious disease characterized by respiratory failure, acute respiratory distress (ARDS), sepsis, myocarditis, and acute kidney injury (2). However, endocrine disorders have yet to be explicitly identified in patients with COVID-19. Researchers have looked into the possibility of thyroid dysfunction among the various extra-pulmonary manifestations. In this review, thyroid dysfunction in patients with COVID-19 and an of overview thyroid diseases probably related to COVID-19 were explored.

Corresponding author/iletişim kurulacak yazar: ozlemcash@yahoo.com

Submitted/Başvuru: 19.05.2021 • Revision Requested/Revizyon Talebi: 27.06.2021 •

Last Revision Received/Son Revizyon: 27.06.2021 • Accepted/Kabul: 28.06.2021 • Published Online/Online Yayın: 24.09 .2021 


\section{SARS-CoV-2 and thyroid gland}

The receptor-binding domain of SARS-CoV-2 uses host angiotensin-converting enzyme 2 (ACE2) for a fusion of viral and host cell membranes. The thyroid, pancreas, intestine, testis, ovary, adrenal glands, and pituitary are among the endocrine organs that express ACE2 $(2,3)$. Recently, intestine, testis, kidneys, heart, thyroid, and adipose tissue were shown to have the greatest levels of ACE2 expression. Only in males, ACE2 expression levels demonstrated strong positive associations with CD8+ T cell enrichment and interferon reaction markers in the thyroid gland (4).

In 2002, it was observed that the severe acute respiratory syndrome (SARS) epidemic caused some abnormalities in the thyroid function. Although SARS-CoV was isolated in endocrine organs including parathyroid, pituitary, pancreas, adrenal gland, it could not be detected in the thyroid, testis, ovary and uterus (5). Wei $L$ et al. showed that thyroid glands in autopsies of five SARS cases were extensively affected by the disease with substantial injury to the follicular epithelial cells and the para-follicular cells (6). It was characterized by destruction of the follicular epithelium and desquamation of the epithelial cells into the follicular lumen.

They revealed presence of apoptosis by the TUNEL assay but no inflammatory infiltrate or features of cellular necrosis (6). However, Yao et al. evaluated pathological alterations in individuals who died of COVID-19 using minimally invasive autopsies from several organs. The thyroid follicular morphology was normal, although lymphocytic infiltration in the interstitium was seen (7). SARS-CoV-2 was not discovered in the thyroid gland by tissue immunohistochemistry or PCR $(8,9)$. By using direct molecular analysis of surgical samples of thyroid tissue, Rotondi et al. demonstrated that the ACE-2 receptor mRNA is expressed in thyroid follicular cells, making them a possible target for SARS-CoV-2 invasion (10).

\section{COVID-19 and thyroid dysfunction including non-thy- roidal illness syndrome}

Evidence supports that patients with COVID-19 who are followed up in an intensive care unit may develop thyroid dysfunction as a non-thyroidal illness syndrome (NTIS). Despite the fact that the pathways causing the NTIS are complex, circulating cytokines are thought to be the primary mediators because of their various effects on the hypothalamic-pituitary-thyroid (HPT) axis, circulating thyroid hormone-binding proteins, and thyroid hormone peripheral metabolism (11). Recently, Lania et al. evaluated thyroid function tests and serum interleukin-6 (IL-6) values in 287 patients hospitalized for COVID-19 in non-intensive care units. In the regression analysis, thyrotoxicosis was detected in 58 patients (20.2\%) (overt in 31 cases), and thyrotoxicosis was found to be significantly associated with higher IL-6. They concluded that COVID-19 may be attributed to a greater risk of thyrotoxicosis in a relationship with systemic immune activation caused by the SARS-CoV-2 infection (12). Chen et al. reported low tyroid sitimulating hormon (TSH) and total triiodothyronine (T3) levels during the course of their COVID-19 infection due to NTIS or the direct pituitary effect of the virus (13).

Müller et al. compared patients admitted to a high intensity of care unit (HICU) in 2020 because of COVID-19 (HICU-20 group), with those admitted to HICU (nonCOVID-19) in 2019 (HICU-19 group) and patients with COVID-19 who were admitted to the low intensity of care units (LICU-20 group) (14). Thirteen (15\%) of 85 patients in the HICU-20 group had thyrotoxicosis (defined as TSH $0.28 \mathrm{mIU} / \mathrm{L}$ and/or free thyroxine (FT4) $>21.9 \mathrm{pmol} / \mathrm{L}$ ), compared to one $(1 \%)$ of 78 patients in the HICU-19 group ( $p=0.002)$ and one (2\%) of 41 patients in the LICU20 group ( $p=0.025)$. The number of males was higher in the HICU-20 group (nine [64\%] men and five [36\%] women; $\mathrm{p}=0.017$ ), and they had higher $\mathrm{C}$-reactive protein (CRP) levels and free thyroxine concentrations. After 55 days of follow-up, euthyroid status was maintained in $75 \%$ of patients (6/8) with $25 \%$ (2/8) of them developing hypothyroidism. They concluded their finding as a combination of thyrotoxicosis (possibly due to subacute thyroiditis) and NTIS (14). However, Kohoo et al. followed up 456 patients from 3 different London Hospitals with a clinical suspicion of COVID-19 (15). The majority of patients (86.6\%) presenting with COVID-19 were euthyroid, with none presenting with overt thyrotoxicosis after excluding the potential interference of cortisol on TSH. Of the participants in $5.1 \%$ had subclinical hypothyroidism, $0.6 \%$ had overt hypothyroidism. Secondary hypothyroidism was suspected in eight patients (2.4\%). TSH and FT4 levels were mildly reduced, which was consistent with an NTIS. Lui et al. showed that $13.1 \%$ had thyroid dysfunction among 191 patients with mild to moderate COVID-19. Ten patients had isolated low FT3, with normal TSH and FT4 levels, indicating a possible NTIS. Ten patients had isolated low TSH, indicating subclinical thyrotoxicosis related to thyroiditis, albeit autoimmunity was likely a factor in two of them. Another patient's subclinical hypothyroidism was almost certainly caused by autoimmune thyroiditis (16). Recently, abnormal thyroid function tests were observed in 62 patients $(16.9 \%)$ in another study from this group. None of the patients showed overt thyrotoxicosis or hypothyroidism. NTIS was found in twenty-seven patients (7.4\%). Five of the patients had pre-existing autoimmune thyroid conditions (17). Gao et al. evaluated thyroid function tests in patients with mild COVID-19, survivors, and nonsurvivors from COVID-19 (18). TSH and FT3 levels, but not FT4 levels, were significantly lower in patients with severe COVID-19 than those in patients with mild COVID-19. 
Patients with severe COVID-19 had lower FT3 levels, which projected all-cause mortality. Also, Schwarz et al. reported that patients with a low FT3 (in the lowest tertile of FT3 values) had a significantly higher disease severity and increased mortality (40\% mortality rate) compared with patients with a higher FT3 $(5 \%$ mortality rate in the higher tertiles) (19). Campi et al. found that suppressed TSH levels were observed in $39 \%$ of patients at admission or during hospitalization and were related with low FT3 in half of the cases. They hypothesized that COVID-19 causes a combined effect in the hypothalamic-pituitary level and peripheral organs due to cytokine release (20).

In conclusion, numerous studies in COVID-19 patients reveal that the NTIS is the most often observed alteration in thyroid diseases.

\section{Subacute thyroiditis}

SAT is an inflammatory disease of the thyroid associated with painful thyroid enlargement. Anterior neck pain radiating to the jaw and ear, malaise, fatigue, myalgia, and arthralgia are typical symptoms of SAT. A mild to moderate fever is often seen, sometimes occasionally exceeding $40^{\circ} \mathrm{C}$, rising especially at night. SAT clinic may reach its peak within 3 to 4 days and disappears within a week, but usually, the onset extends over 1 to 2 weeks and persists for 3 to 6 weeks (21). Clinic presentation of SAT and COVID-19 may be similar to each other in many aspects. SAT incidence is four times higher in women than in men and SAT is more frequent between ages 4050 years (22). Several studies showed that susceptibility to the disease and recurrence risk are associated with human leukocyte antigens (HLA) mainly HLA-Bw35, but also HLAB67, HLA-B15/62, and HLA-Drw8 (23, 24). Previous viral infection (around 2-6 weeks earlier) caused by viruses including Coxsackie virus, Epstein-Barr virus, adenoviruses, influenza viruses, mumps, measles, primary human immunodeficiency virus infection is thought to be a trigger factor (25). SAT is defined by elevated erythrocyte sedimentation rate (ESR) and CRP level, typical ultrasound findings including inhomogeneous hypo-echogenic texture with diminished vascularity and laboratory markers of thyrotoxicosis. Symptomatic treatment includes nonsteroidal anti-inflammatory drugs (NSAIDs), glucocorticoids (21).

First, Brancatella et al. presented an 18-year-old woman with SAT diagnosis which occurred after 2 weeks of SARS-CoV-2 infection (26). Prednisone ( $25 \mathrm{mg} /$ day as the starting dose) was given to the patient, thyroid function and inflammatory markers of the patient normalized in 40 days. Ippolito et al. reported a 69-year-old woman with COVID-19 during the recovery phase following back surgery. Previously, she had a non-toxic nodular goiter and she diagnosed with thyrotoxicosis during COVID-19. They considered SAT because the patient responded to steroids, not methimazole (27). Asfuroglu et al. reported a 41-year-old woman with SAT and they warned physicians should be aware of screening SAT patients for COVID-19 (28). Ruggeri et al. described a 43-year-old woman who developed SAT with thyrotoxicosis six weeks after SARS-COV-2 infection. Oral prednisone $(25 \mathrm{mg} /$ day as the starting dose) was given to the patient and progressive remission of symptoms and signs and euthyroid status was provided after four weeks (29). Brancatella et al. described an additional four patients with SAT after COVID-19 (30). Until now, 22 cases of SAT potentially associated with SARS-CoV-2 infection have been reported in literature (31-39). In a recent review, SAT was found more frequent in women than in men (18 women/4 men), patients with a mean age of $39 \pm 11$ years during or after ( $21 \pm 11$ days) an episode of COVID-19. These patients have mild symptoms and signs including fever, myalgia, asthenia, palpitations, weight loss, and anterior neck pain or asymptomatic. Most patients were treated with $\beta$-blockers, aspirin, glucocorticoids (prednisone 25-40 mg) gradually discontinued over an average of 3 or 4 weeks. Despite a short follow-up (35 \pm 12 days), euthyroid status was achieved after a short duration of subclinical hypothyroidism in most patients (40).

\section{Graves' disease}

Graves' disease (GD) is an autoimmune disorder caused by stimulating thyroid autoantibodies that results in thyroxine overproduction leading to hyperthyroidism. The etiology of GD is not clear. It has been suggested that different environmental conditions (i.e. infections, smoking, stress, radiation, medications, iodine, etc.) can trigger GD especially in genetically vulnerable individuals

The significance of stress in the development of hyperthyroidism in GD patients is still debated. In cross-sectional studies, stressful life events (SLE) have been shown to be more common in the months before the development of GD (47). Vita et al. evaluated the relationship of SLE with the onset and outcome of GD. Patients with SLE experienced at least one exacerbation or relapse prior to each exacerbation or relapse. The patients who experienced more exacerbation or relapse lived more SLE than the patients with remission (48). Previously, we showed that the number and impact of negative SLE in GD patients were higher when compared to healthy controls according to Life Experience Survey (49). Recently we have recommended methimazole and beta-blocker combination for initial therapy and considered dietary changes and RAI treatment unadvisable during the COVID-19 pandemic (50).

\section{CONCLUSION}

In patients who were severely affected during the course of COVID-19, changes in thyroid function may relate to NTIS but there may be a relation with a specific thyroid 
disease after COVID-19. Thyroid dysfunction could be observed during and after COVID-19 and, therefore, it is expected that some new-onset or recurrent thyroid dysfunctions could be attributed to a recent SARS-CoV-2 infection. Physicians should be aware of possible relationships between thyroid dysfunction and COVID-19, which should be researched by prospective studies.

Peer Review: Externally peer-reviewed.

Conflict of Interest: Authors declared no conflict of interest.

Financial Disclosure: Authors declared no financial support.

Hakem Değerlendirmesi: Dış bağımsız.

Çıkar Çatışması: Yazarlar çıkar çatışması beyan etmemişlerdir.

Finansal Destek: Yazarlar finansal destek beyan etmemişlerdir.

\section{REFERENCES}

1. Guan WJ, Ni ZY, Hu Y, Liang WH, Ou CQ, He JX, et al. Clinical characteristics of coronavirus disease 2019 in China. N Engl J Med 2020;382(18):1708-20. [CrossRef]

2. Pal R, Banerjee M. COVID-19 and the endocrine system: exploring the unexplored. J Endocrinol Invest 2020;43(7):1027-31. [CrossRef]

3. Liu F, Long X, Zhang B, Zhang W, Chen X, Zhang Z. ACE2 expression in pancreas may cause pancreatic damage after SARS-CoV-2 infection. Clin Gastroenterol Hepatol 2020;18(9):2128-2130.e2. [CrossRef]

4. Li MY, Li L, Zhang Y, Wang XS. Expression of the SARSCoV-2 cell receptor gene ACE2 in a wide variety of human tissues. Infect Dis Poverty 2020;9(1):45. [CrossRef]

5. Ding $Y, \mathrm{He}$ L, Zhang Q, Huang Z, Che X, Hou J, et al. Organ distribution of severe acute respiratory syndrome (SARS) associated coronavirus (SARS-CoV) in SARS patients: Implications for pathogenesis and virus transmission pathways. J Pathol 2004;203(2):622-30. [CrossRef]

6. Wei L, Sun S, Xu CH, Zhang J, Xu Y, Zhu H et al. Pathology of the thyroid in severe acute respiratory syndrome. Hum Pathol 2007;38(1):95-102. [CrossRef]

7. Yao XH, Li TY, He ZC, Ping YF, Liu HW, Yu SC, et al. Histopathological study of new coronavirus pneumonia (COVID-19) in three patients. Zhonghua Bing Li Xue Za Zhi 2020;849(5):411-7.

8. Barton LM, Duval EJ, Stroberg E, Ghosh S, Mukhopadhyay S. COVID-19 autopsies, Oklahoma, USA. Am J Clin Pathol 2020;153(6):725-33. [CrossRef]

9. Bradley BT, Maioli H, Johnston R, Chaudhry I, Fink SL, Xu $\mathrm{H}$, et al. Histopathology and ultrastructural findings of fatal COVID-19 infections in Washington State: a case series. Lancet 2020;396(10247):320-32. [CrossRef]

10. Rotondi M, Coperchini F, Ricci G, Denegri M, Croce L, Ngnitejeu ST, et al. Detection of SARS-COV-2 receptor ACE-2 mRNA in thyroid cells: a clue for COVID-19-related subacute thyroiditis. J Endocrinol Invest 2021;44(5):1085-90. [CrossRef]
11. Croce L, Gangemi D, Ancona G, Liboà F, Bendotti G, Minelli $L$, et al. The cytokine storm and thyroid hormone changes in COVID-19. J Endocrinol Invest 2021;44(5):891904. [CrossRef]

12. Lania A, Sandri MT, Cellini M, Mirani M, Lavezzi E, Mazziotti G. Thyrotoxicosis in patients with COVID-19: THE THYRCOV STUDY. Eur J Endocrinol 2020;183(4):381-7. [CrossRef]

13. Chen $M$, Zhou $W, X u$ W. Thyroid function analysis in 50 patients with COVID-19: A retrospective study. Thyroid 2021;31(1):8-11. [CrossRef]

14. Muller I, Cannavaro D, Dazzi D, Covelli D, Mantovani G, Muscatello A, et al. SARS-CoV-2-related atypical thyroiditis. Lancet Diabetes Endocrinol 2020;8(9):739-41. [CrossRef]

15. Khoo B, Tan T, Clarke SA, Mills EG, Patel B, Modi M, et al. Thyroid function before, during and after Covid-19. J Clin Endocrinol Metab 2021; 23:106(2): e803-11. [CrossRef]

16. Lui DTW, Lee CH, Chow WS, Lee ACH, Tam AR, Fong CHY, et al. Thyroid dysfunction in relation to immune profile, disease status and outcome in 191 patients with Covid-19. J Clin Endocrinol Metab 2021;23:106(2):e926-35. [CrossRef]

17. Lui DTW, Lee CH, Chow WS, Lee ACH, Tam AR, Fong CHY et al. Role of non-thyroidal illness syndrome in predicting adverse outcomes in COVID-19 patients predominantly of mild-to-moderate severity. Clin Endocrinol (Oxf) 2021;95(3):469-77. [CrossRef]

18. Gao W, Guo W, Guo Y, Shi M, Dong G, Wang G, et al. Thyroid hormone concentrations in severely or critically ill patients with Covid-19. J Endocrinol Invest 2021; 44(5):103140. [CrossRef]

19. Schwarz Y, Percik R, Oberman B, Yaffe D, Zimlichman E, Tirosh $A$. Sick euthyroid syndrome on presentation of patients with COVID-19: A potential marker for disease severity. Endocr Pract 2021;27(2):101-9. [CrossRef]

20. Campi I, Bulgarelli I, Dubini A, Perego GB, Tortorici E, Torlasco $C$, et al. The spectrum of thyroid function tests during hospitalization for SARS COV-2 infection. Eur J Endocrinol 2021;184(5):699-709. [CrossRef]

21. Samuels MH. Subacute, silent, and postpartum thyroiditis. Med Clin North Am 2012;96:223-33. [CrossRef]

22. Alfadda AA, Sallam RM, Elawad GE, Aldhukair H, Alyahya MM. Subacute thyroiditis: clinical presentation and long term outcome. Int J Endocrinol 2014;2014:794943. [CrossRef]

23. Erdem N, Erdogan M, Ozbek M, Karadeniz M, Cetinkalp $S$, Ozgen AG, et al. Demographic and clinical features of patients with subacute thyroiditis: results of 169 patients from a single university center in Turkey. J Endocrinol Invest 2007;30(7):546-50. [CrossRef]

24. Stasiak M, Tymoniuk B, Stasiak B, Lewiński A. The risk of recurrence of subacute thyroiditis is HLA-Dependent. Int J Mol Sci 2019;20(5):1089. [CrossRef]

25. Desaillud R, Hober D. Virus and thyroiditis: an update. Virol J 2009;6:5. [CrossRef]

26. Brancatella A, Ricci D, Viola N, Sgrò D, Santini F, Latrofa F. Subacute thyroiditis after Sars-COV-2 infection. J Clin Endocrinol Metab 2020;105(7):dgaa276. [CrossRef]

27. Ippolito S, Dentali F, Tanda ML. SARS-CoV-2: a potential trigger for subacute thyroiditis? Insights from a case report. J Endocrinol Invest 2020;43(8):1171-2. [CrossRef]

28. Asfuroglu Kalkan E, Ates I. A case of subacute thyroiditis associated with Covid-19 infection J Endocrinol Invest 2020;43(8):1173-4. [CrossRef] 
29. Ruggeri RM, Campennì A, Siracusa M, Frazzetto G, Gullo D. Subacute thyroiditis in a patient infected with SARSCOV-2: an endocrine complication linked to the COVID-19 pandemic. Hormones (Athens) 2021;20(1):219-21. [CrossRef]

30. Brancatella A, Ricci D, Cappellani D, Viola N, Sgrò D, Santini F, Latrofa F. Is subacute thyroiditis an underestimated manifestation of SARS-CoV-2 infection? Insights From a Case Series. J Clin Endocrinol Metab 2020;105(10):dgaa537. [CrossRef]

31. Mattar SAM, Koh SJQ, Rama Chandran S, Cherng BPZ. Subacute thyroiditis associated with COVID-19. BMJ Case Rep 2020;13(8):e237336. [CrossRef]

32. Khatri A, Charlap E, Kim A. Subacute thyroiditis from COVID-19 infection: A case report and review of literature. Eur Thyroid J 2021;9(6):324-8. [CrossRef]

33. Campos-Barrera E, Alvarez-Cisneros T, Davalos-Fuentes M. Subacute thyroiditis associated with COVID-19. 2020 Sep 28; 2020:8891539. [CrossRef]

34. Ruano R, Zorzano-Martinez M, Campos A, Rius F, Hernández M. Subacute thyroiditis might be a complication triggered by SARS-CoV-2. Endocrinol Diabetes Nutr (Engl Ed). 2020 13;S2530-0164(20)30206-8. [CrossRef]

35. Chong WH, Shkolnik B, Saha B, Beegle S. Subacute thyroiditis in the setting of Coronavirus Disease 2019. Am J Med Sci $2021 ; 361(3): 400-2$. [CrossRef]

36. San Juan MDJ, Florencio MQV, Joven MH. Subacute thyroiditis in a patient with coronavirus disease 2019. AACE Clin Case Rep 2020;6(6):e361-4. [CrossRef]

37. Álvarez Martín MC, Del Peso Gilsanz C, Hernández López A. Subacute De Quervain thyroiditis after SARSCoV-2 infection. Endocrinol Diabetes Nutr 2020;S25300164(20)30244-5. [CrossRef]

38. Chakraborty U, Ghosh S, Chandra A, Ray AK. Subacute thyroiditis as a presenting manifestation of COVID-19: a report of an exceedingly rare clinical entity. BMJ Case Rep 2020;13(12):e239953. [CrossRef]

39. Sohrabpour S, Heidari F, Karimi E, Ansari R, Tajdini A, Heidari F. Subacute thyroiditis in COVID-19 patients. Eur Thyroid J 2021;9(6):321-3. [CrossRef]
40. Caron P. Thyroiditis and SARS-CoV-2 pandemic: a review. Endocrine 2021;72(2):326-31. [CrossRef]

41. Antonelli A, Ferrari SM, Ragusa F, Elia G, Paparo SR, Ruffilli I, et al. Graves' Disease: Epidemiology, genetic and environmental risk factors and viruses. Best Pract Res Clin Endocrinol Metab 2020;34(1):101387. [CrossRef]

42. Valtonen W, Ruutu P, Varis K, Ranki M, Malkamäki M, Mäkelä $\mathrm{PH}$. Serological evidence for the role of bacterial infections in the pathogenesis of thyroid diseases. Acta Med Scand 1986;219(1):105-11. [CrossRef]

43. Davies TF. Infection and autoimmune thyroid disease. J Clin Endocrinol Metab 2008;93(3):674-6. [CrossRef]

44. Mateu-Salat M, Urgell E, Chico A. SARS-COV-2 as a trigger for autoimmune disease: report of two cases of Graves' disease after COVID-19. J Endocrinol Invest 2020;43(10):1527-8. [CrossRef]

45. Jiménez-Blanco S, Pla-Peris B, Marazuela M. COVID-19: a cause of recurrent Graves' hyperthyroidism? J Endocrinol Invest 2021;44(2):387-8. [CrossRef]

46. Pastor S, Molina Á Sr, De Celis E. Thyrotoxic crisis and COVID-19 infection: an extraordinary case and literature review. Cureus 2020;12(11):e11305. [CrossRef]

47. Dayan CM. Stressful life events and Graves' disease revisited. Clin Endocrinol (Oxf) 2001;55(1):13-4. [CrossRef]

48. Vita R, Lapa D, Trimarchi F, Benvenga S. Stress triggers the onset and the recurrences of hyperthyroidism in patients with Graves' disease. Endocrine 2015;48(1):254-63. [CrossRef]

49. Topcu CB, Celik O, Tasan E. Effect of stressful life events on the initiation of Graves' disease. Int J Psychiatry Clin Pract 2012;16(4):307-11. [CrossRef]

50. Agcaoglu O, Sezer A, Makay O, Erdogan MF, Bayram F, Guldiken S, et al. Management of endocrine surgical disorders during COVID-19 pandemic: expert opinion for non-surgical options. Updates Surg 2021:1-11. [CrossRef] 